\title{
Existence of Intention and Classification of Spiritual Quality of Students at the Boarding School Jagad 'Alimussirry Surabaya
}

\author{
A Syarifuddin' ${ }^{1}, \mathbf{S} \mathbf{N}$ 'Aini $^{2}$ \\ ${ }^{1}$ Islamic Building School of Jagad Alimussirry Surabaya, Indonesia \\ Email: nuril7ainy@gmail.com
}

\begin{abstract}
Scientific writing aims to find out the intentions and sincerity correctly, efforts must be made to improve the spiritual quality of students. This research is a qualitative analysis research with case study method. Data collection techniques used are observation, interviews, and documentation. Data sources came from the Jagad 'Alimussirry Student Boarding School. The results of the analysis show that something done with intention and sincerity only gives to God so that it becomes a perfect charity from one's worship. Before charity must be careful so that the charity that is done can be accepted by God. People who purify the heart of all defilements by avoiding evil, maintain honesty in words and deeds, their hearts will become clean, can emit positive energy and can meet Allah SWT.
\end{abstract}

Keywords: Intention; sincerity; Spiritual

\section{INTRODUCTION}

Every deed done must be based on a sincere heart solely to expect Allah's pleasure, because sincerely one's faith will be perfect and the charity will be accepted. But sincere charity is not enough if it is not accompanied by the right intention, namely the intention that comes from the heart. This shows that every act of worship depends on intention and someone will only get from what he intended. Because intention is the spirit of worship. Just as the body will not be worth without spirit.

The intention must be accompanied by deliverance from all lust, ugliness and worldliness, but to do good deeds with sincere intentions is not easy. Don't think it can be done by every hand that wants it and can be obtained with a simple effort without hassle. Intention is the starting point of a journey to a destination. The final goal is determined by the initial intention before the trip. Worship that is driven by the right intention will be a solid worship if accompanied by sincerity, with sincerity making passion and beauty in worship. Actions that manifest in the physical are very closely related to the form of spiritual secrets which include the heart in the form of sincerity. If worship is equated with physical, then sincerity is the soul. Because worship that is not sincere is the same as the body without spirit.

Therefore, Allah bestows warid on His servants in the form of intentions and intentions must be colored by sincerity. While sincerity is only obtained in the hearts of people who understand the knowledge of monotheism that can instill the attitude of life Laa Hawla Walaa Quwaata Illa Billahil 'Aliyyil' Adziim. 


\section{METHOD}

This research is a qualitative analysis research with case study method. Data collection techniques used are observation, interviews, and documentation. Data sources were obtained from students of Islamic Boarding School Jagad 'Alimussirry Surabaya.

\section{DISCUSSION}

\section{Study of Intention and Ikhlas}

\section{Understanding Intention}

The scholars who are knowledgeable are broad and profound, devoted and devout hukama the perfect believer has talked about intentions with different editors but with adjacent meanings. Intention is a charity spirit. As well as the bodies are not worth without the spirit, as well as a charity he is not worth without intention. Because intention is the heart of the heart and the controller of the heart. If only the place of intention is not in the heart, the value of the heart cannot be known.

This shows that intention is something that cannot be seen by anyone because it is in the heart, only God can see and judge it. Indeed what Allah wants from His servants is taqwa. Whereas the place of taqwa is in the heart, and taqwa is sincerity.

Rasulullah SAW said, "The intention of a believer is better than his charity and the intention of a wicked one is worse than his charity". The Prophet said that because intention is a matter of the heart and the act of the heart is worth seventy times the deed born. It is stated that if a servant remembers Allah Almighty. In his heart, Allah will record the dhikr with His hand in His record. When the angel shows the record of the servant's charity to God. He added the dhikr of the servant's heart to the charity record carried by the angel. God will record himself specifically the dhikr done with the heart for a servant, and the angel does not know the dhikr. And on the Day of Resurrection there will be no reply for this dhikr expert other than seeing the Face of the Essence that he has thought about in the world.

The righteousness of charity depends on the straightness of the heart and the straightness of the heart depends on the straightness of intention. People whose hearts are clean, then the intention is clean. People whose hearts are dirty, their intentions are dirty too.

This revealed that intentions were one of the legal requirements for charity. Charity without intentions is illegal. Something that becomes the validity of charity is naturally better than charity itself. Such as a servant who intends to do good deeds, but for some reason, he does not have time to do it, it is better than charity without intention.

\section{Sincere}

Ikhlas is cleansing the words and actions of anger. Know, sincere actions will grow in humans if they are able to be honest in words, deeds, and in living their lives must be done in order to expect Allah's blessing. A makrifat expert argues that the charity assessment done by someone depends on his motivation.

Indeed, every human deed is never separated from the attention of Allah. He will judge, whether you do this charity only for Him or for humans called riya'. If you are sincere intentions only for Him, then you will be lucky. But if you do it because only other desires are out of sincerity, then your charity is in vain, even sin.

Dzun-nun al misry argues about the signs of sincerity, namely there are three cases; First is the praise and reproach of the same person for him. Secondly, not in the act of obedience when he was doing the charity. Third, the charity is carried out only to expect the reward of the afterlife and blessing of Allah.

Therefore arranging the intentions and sincerity that is truly from the heart because Allah is an obligation for every person who certainly wants every charity worth 
worshiping and recorded and accepted by Allah.

\section{Spiritual Study}

\section{Spiritual Understanding}

The meaning of the word spirit. According to Vitale, spirit is that which is traditionally believed to be a vital principle for animating force within living beings. The soul is a hereditary belief which is an important beginning to revive the power in life.

The concept of spirit comes from Latin spirits which means breath. the modern term refers to the energy of life and part of the self which includes emotions, characters. in developing spiritual will see something that is brighter and humorous, and regain joy, energy, and perseverance.

\section{Santri's Efforts in Arranging Intention and Ikhlas}

If you claim to love Allah and His Prophet, then you must prove your love. To prove it you must carry out all His commands and stay away from His prohibitions and acknowledge that everything in the universe is proof that God exists as the creator.

Be careful in initiating the intention for the deeds you want to do. Your intention is to do worship but solely seek heaven, so it is the same as working for porters who just want to get paid from their bosses. Even though a coolie who works with the intention to please the skipper's heart, then he will get two kinds of rewards. First the reward in the form of payment and the second is the attitude of the boss who is happy with him. Likewise, if your intentions lead to only Allah, God willing, you will get everything.

You have realized that every charity depends on his intentions and not on his actions. But it must also be remembered again, even though you have set an intention, but if the intention is not sincere, then it is like a cage that has no contents. Like a soulless body.
Charity is the incarnation of intentions and desires in the heart. There are intentions and desires in the heart, then realized in action, then it is called charity. Charity will not fail if there is a match with intention. But the intention alone is not enough if not sincere.

\section{Secrets of Intention and Ikhlas in Affecting Spiritual Quality}

Sincerity and intentions is the heart of the receipt of an act of worship beside the Knower, because both are located in the liver, it is only Allah who knows the content of the intention and sincere. Improving our spiritual quality to Allah SWT is not as easy as imagined, because it requires the intention and sincerity that truly only hopes for Allah's pleasure. And to organize intentions and sincerity correctly is not an easy matter for a santri.

Yahya ibn mu'adz al-razi revealed, that patience in feeling the sweetness of charity is a sign of sincerity. By continuing to fight against the desires of lust is a sign of God's salvation and closeness. People who have felt the sweetness of loving God will be surrounded. He cannot go anywhere, cannot escape the trap of God's love. He will not die, will not be blessed, and will not be buried except in the love of God.

A charity will not be truly sincere until it is clean of three things: desire seen by beings, the influence of lust, and hope of being rewarded by God. A person is said to be sincere when he is born to humans, while his mind, silence, his movements are sincere for Allah SWT, not polluted by lust, riya', and greed. Let him review his loneliness, silence, hunger, tears, and sadness. His solitude must dampen all his world busyness, his silence must suppress his speech, his hunger must reduce his lust, his cry must reduce his laughter, and his sadness must reduce his joy.

The exposure contains a lot of tafakkur and tadabbur ingredients. No one understands it except the person who understands and no one 
is able to carry it out except the person who gets his guidance and guidance

\section{CONCLUSION}

Intention and sincerity is the secret between creatures and the Almighty, by submitting to Allah. Life is only for God. Before charity must be careful so that the charity that we do will be worthy of worship and recorded by God. People whose hearts are clean, their intentions are clean. Cleansing the heart of all the impurities of the heart, keeping away from evil, keeping honesty in words and deeds, it will make the heart clean, can emit positive energy and be able to meet with Allah SWT.

\section{REFERENCES}

[1] A. Qolamy and A. Fajar, "The essence of the Al Hikam Book", Gitamedia Press, 2005.

[2] A. Cadruzaman, "The Secret Of Ikhlas", Jakarta: PT Setambi Ilmu Semesta, 2008.

[3] A. Ezra, "The Thrue Power Of Ikhlas", Yogyakarta: Hijrah, 2007.

[4] Y. Al-Qaradhawi, "Intention and Ikhlas", Jakarta: Library of Al Kautsar, 2008. 